\title{
Analyzing Constraints and Opportunities of Urban Agriculture in the Greenbelt of Ouagadougou, Burkina Faso
}

\author{
Delphine Bernadette Ouédraogo ${ }^{1,}$, , Bassirou Belem², Delwendé Innocent $\mathrm{Kiba}^{3}$, \\ Zacharia Gnankambary ${ }^{3}$, Hassan Bismarck Nacro ${ }^{4}$, Papaoba Michel Sedogo ${ }^{3}$ \\ ${ }^{1}$ Université Joseph Ki-Zerbo, Institut de Génie de l'Environnement et du Développement Durable, Ouagadougou, Burkina Faso \\ ${ }^{2}$ Centre National de Semences Forestières, Ouagadougou, Burkina Faso \\ ${ }^{3}$ Institut de l'Environnement et de Recherches Agricoles, Ouagadougou, Burkina Faso \\ ${ }^{4}$ Université Nazi Boni, Institut du Développement Rural, Bobo-Dioulasso, Burkina Faso
}

Email address:

delberno@gmail.com (D. B. Ouédraogo), belbass@hotmail.com (B. Belem), innokiba@yahoo.fr (D. I. Kiba), gnank_zach@hotmail.com (Z. Gnankambary), nacrohb@yahoo.fr (H. B. Nacro), michel_sedogo@yahoo.fr (P. M. Sedogo)

${ }^{*}$ Corresponding author

\section{To cite this article:}

Delphine Bernadette Ouédraogo, Bassirou Belem, Delwendé Innocent Kiba, Zacharia Gnankambary, Hassan Bismarck Nacro, Papaoba Michel Sedogo. Analyzing Constraints and Opportunities of Urban Agriculture in the Greenbelt of Ouagadougou, Burkina Faso. Agriculture, Forestry and Fisheries. Vol. 8, No. 3, 2019, pp. 73-80. doi: 10.11648/j.aff.20190803.13

Received: June 17, 2019; Accepted: July 10, 2019; Published: July 23, 2019

\begin{abstract}
Urban agriculture (UA) is seen as one of the solutions for ensuring food security in African cities, but it remains marginalized. In Burkina Faso, it is not explicitly taken into account in Agricultural Development Plans. Here we analyze the opportunities and constraints related to the practice of UA in the Green belt of Ouagadougou and provide informations that may be useful to land use decision-makers. The results after a review of literature and field surveys showed that women represented $55 \%$ of producers. The age of the producers was between 21 and 80 years old and that of the farms was between 1 and 70 years old. The surfaces managed are between 0.25 to 5 hectares. The farms found belonged to individuals $65 \%$ or families $35 \%$. About 30 species of plants were grown for consumption or sale at the same proportions. The problems faced by farmers included lack of agricultural inputs and equipment, lack of irrigation water, low soil fertility. The solutions to overcome those problems according to the farmers included, support with fountains, fertilizers and finances. We found that men invested more in market oriented agriculture than women and that farmers who own land invested more in fertilizer application. The land acquisition is continuous and not organized leading to a degradation of the green belt. For a better management of the Green belt we suggest among other things to develop a management plan and set up an exchange framework and precise specifications for the exploitations.
\end{abstract}

Keywords: Land Use, Urban Agriculture, Green Belt, Legislation, Ouagadougou, Burkina Faso

\section{Introduction}

About $85 \%$ of the population in Africa will live in cities by 2020 , leading, among other things, to food insecurity [1] as population growth and increasing urbanization lead to increased food demand [2]. In sub-Saharan Africa, about $26 \%$ of people over the age of 15 , representing 153 million people, suffered from severe hunger during 2014-2015 [3]. According to [4], in countries of sub-Saharan Africa, projections based on population growth and food requirements indicate that agricultural production should be increased by at least $70 \%$ to meet the demand by 2050 . The growth of the African population makes the food supply a major challenge for development policies [5]. Moreover, in African cities, most city dwellers do not grow their own food and are dependent on money to buy food, which makes them vulnerable to higher prices [6]. There is therefore an increased need for urban dwellers to grow more and more plants that can provide them with food. 
Urban agriculture (UA) is one of the solutions for ensuring food security in cities. According to [7], UA is defined as agriculture practiced and experienced in an agglomeration by farmers and inhabitants at the scales of daily life and the territory of application of urban regulation. In this area, farmers (professional and non-professional agriculture, oriented towards long circuits, short circuits or selfconsumption), have reciprocal functional links with the city (food, landscape, recreation, ecology) giving rise to a diversity of observable agri-urban forms in the urban neighborhoods. According to [8], the most important productive sectors of UA include horticulture, animal and feed production, milk production, aquaculture and agroforestry. UA is widespread but informal. However, it has the potential to become an ally in food security and nutrition in the city. Agriculture has become for some 20 years an important issue for food security and it is now considered a food supply modality in cities [9].

The Green belt of Ouagadougou aimed at its creation in 1974 of planting fast growing trees species that can rapidly provide ecosystemic services. These plantations were designed to meet the needs of cities to protect themselves against strong winds, erosion on the one hand, and on the other hand to supply firewood and construction material and to practice market gardening when the canopy allows it. According to [10], urban and peri-urban forests were created around the major cities of other African countries but their maintenance remains a real challenge. For instance, in Senegal, the urban forests were formed in 1935 and included six formations among which, the forest park of Hann in Dakar, classified in 1943 and today actively arranged to accommodate walkers and casual sportsmen. In Niger, the "Green belt" operation launched in 1965 consisted of surrounding the northern zone of Niamey with a strip of trees to protect the capital from the impact of the wind and thus fight against the intrusion of sand and sand dust. Nouakchott's Greenbelt in Mauritania covered more than 1200 ha of trees planted between 1975 and 1991.

The Green belt of Ouagadougou at the time of its creation had to occupy an area of 2100 ha with an annual planting rate of 100 ha. In 1986 the reforested area was estimated at $1032 \mathrm{ha}$, about $21 \mathrm{~km}$ long with a width of $500 \mathrm{~m}$ and a total length of $65 \mathrm{~km}$ [11]. It is composed of fast-growing trees including neem tree Azadirachta indica A. Juss (38\% of planted species), red gum Eucalyptus camaldulensis Dehnh. (36.5\%), yellow cassia Senna siamea (Lam.) H.S. Irwin et Barneby (15.5\%), white teack Gmelina arborea Roxb. Ex Sm. (3\%), and other exotic species (2\%) and local species (5\%) [12]. The exotic species account for about $93 \%$. For the forest service of the time, the planting of local species was discarded because of difficulties to breed those species in nursery given their slow vegetative growth. The Green belt was proposed in the Master Plan of Urban Development of Ouagadougou in 1986 [13].

Today, the Green belts in African cities are degrading despite the efforts made by the governments to protect or rehabilitate them [14-16]. The Green belt of Ouagadougou is nowadays the subject of reflection at the highest administrative level to find solutions to its rehabilitation [12, $16,17,18]$.

This paper aims to contribute to the reflection by providing information to decision-makers for a better rehabilitation of Green-belts and the promotion of urban agriculture for a better supply of food to the city dwellers. First, we characterized the agricultural practices in the Green belt, then identified and analyzed the causes of its occupation by farmers, and finally proposed solutions for a sustainable agriculture in the city of Ouagadougou.

\section{Material and Method}

\subsection{Study Sites}

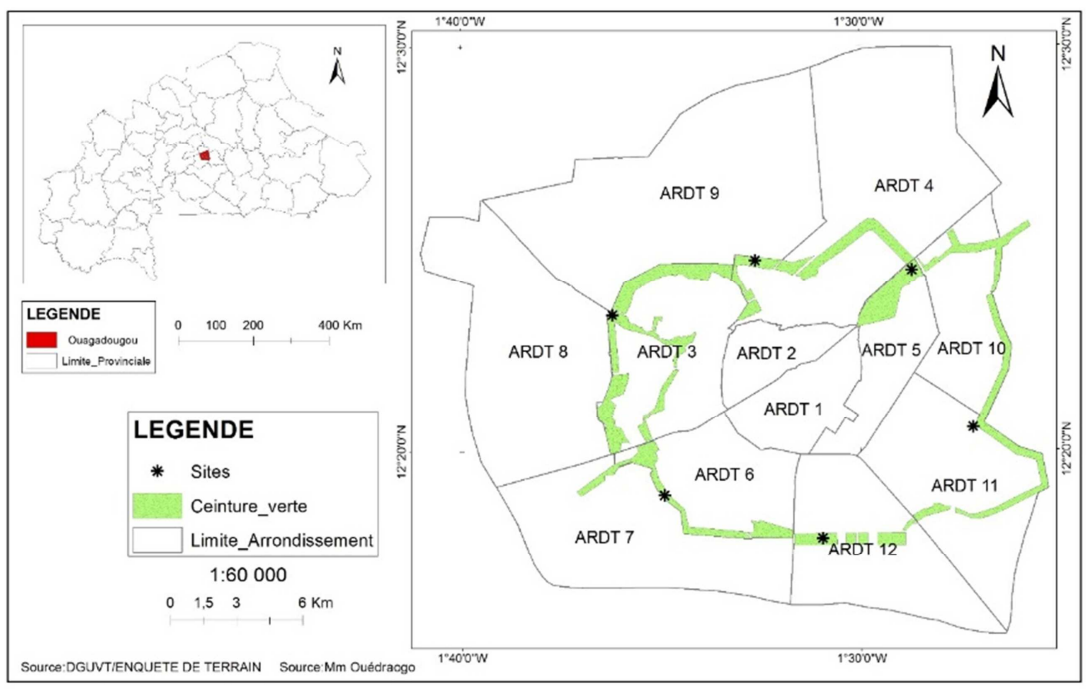

Figure 1. Localization of the study sites and the Green belt of Ouagadougou, Burkina Faso. 
The study was conducted in 2017 and 2018 in the city of Ouagadougou $\left(1240^{\prime} \mathrm{N} 1^{\circ} 40^{\prime} \mathrm{W}\right.$ and $12^{\circ} 10^{\prime} \mathrm{N}$ at $\left.1^{\circ} 10^{\prime} \mathrm{W}\right)$, capital of Burkina Faso (Figure 1). Ouagadougou has a rainy season of about 5 months (June to October) ranged between 600 to $900 \mathrm{~mm}$ and a dry season of about 7 months [19].

The soils encountered in the city of Ouagadougou are mainly tropical ferruginous types, based on fissured granites. They are characterized by their low organic matter contents and also their low levels of mineral elements and their fragile structure and are very sensitive to erosion [20].

\subsection{Survey}

The methodology used includes a literature review and field surveys. The purpose of the literature review is to appreciate the context for the creation of the Green belt, the objectives assigned to this entity, the efforts undertaken by the government through the Forest Service and the funding agencies in the design and implementation of the Green belt project, the involvement of local populations or urban dwellers in the implementation of activities. The surveys were conducted during the rainy season (July and September 2018). The September period corresponds to the beginning of maturity of the main crops grown on farms, namely white sorghum (Sorghum bicolor (L.) Moench), maize (Zea mays L.), groundnut (Arachis hypogea L.). The surveys targeted six (6) sites including 3 sites for market gardening corresponding to the number of shallows in the Green belt and 3 sites for rainfed crops. A total of and 60 (10 per site) producers was considered. Semi-structured interviews were conducted using a pretested survey form. In each farm, the data collected relate to the identity of the farmer, his level of schooling, the type of farm (family or private), the area exploited, the mode of acquisition of the space, the cultivated species, the objective of the production, the cropping practices and finally the opportunities and constraints related to the exploitation of the site. The names of the plants were recorded in the Mooré language, which is spoken by the majority of the population of the city of Ouagadougou. The correspondences between the names in Mooré, French and scientific names refer to the publications of [21-24].

\subsection{Data Analysis}

The answers given to the quantitative questions were estimated using quotation frequencies calculated as follow $\mathrm{Fc}=\mathrm{n}=\mathrm{n} / \mathrm{N} \times 100$, where $\mathrm{Fc}$ corresponds to the Frequency of quote, $n$ the number of times the same response was given by the informants and $\mathrm{N}$ the total number of responses given by all informants. The collected data were stored in the Excel software and then analyzed using the MINITAB software version 18. Principal Component Analysis was performed on the centered-standardized survey data using with CANOCO 5.1 to summarize part of the variation of cropping practices that can be explained by some socio-economic conditions of the farmers. The informations about education, type of farming, fertilization, market orientation and land tenure were encoded as dummy variables using 1 for the presence and 0 for the absence. The information about gender was encoded 1 for man and 0 for woman.

\section{Results}

\subsection{Characteristics of the Farms}

Producers in the Greenbelt comprised 55\% women and $45 \%$ men between 21 and 80 years of age These age groups were distributed between 21-40 years, 20 farmers; 41-50 years old, 15 farmers; 51- 60 years old, 14 farmers; 60 - 80 years, 11 farmers. The Figure 2 A shows that about $70 \%$ of the producers did not have any land tenure status and less than $5 \%$ were land owners. The age of the farms was between 1 and 70 years old with $50 \%$ less than 10 years old and $25 \%$ between 11 and 20 years old (Figure $2 \mathrm{~B}$ ).

A

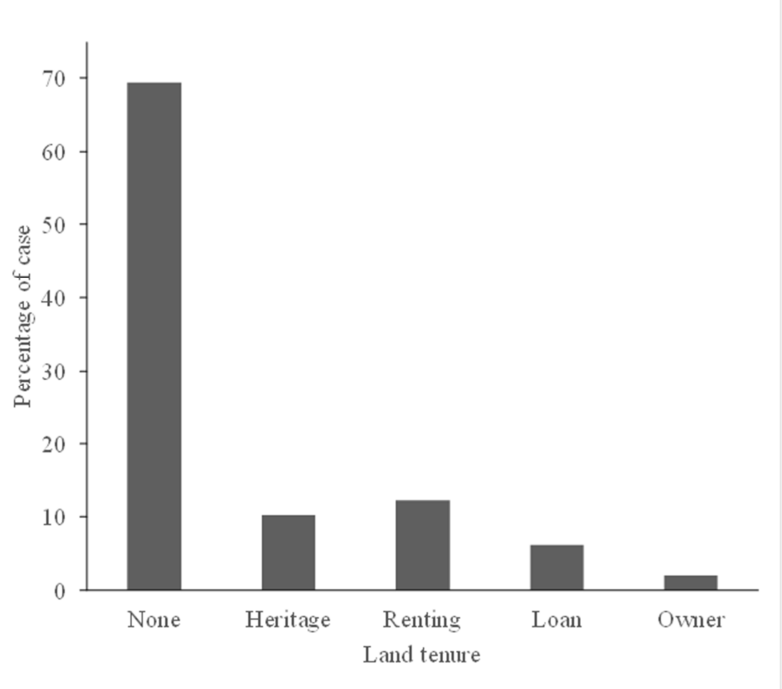

B

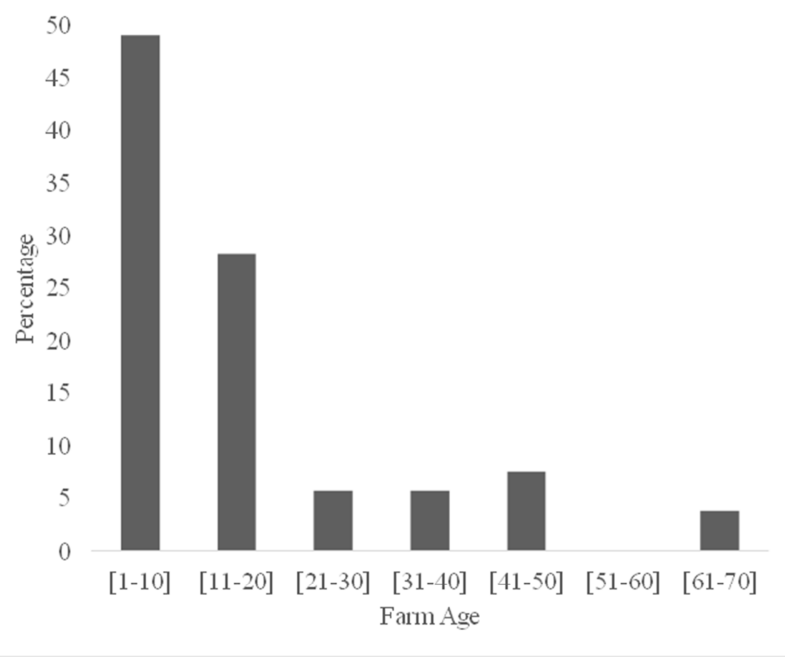

Figure 2. Land tenure and Farm age in the Green Belt of Ouagadougou, Burkina Faso. 
The areas exploited ranged from 0.25 to 5 hectares with an average of 0.88 hectares. The areas of 0.5 hectares were the most represented (Figure $3 \mathrm{~A}$ ). Individual farms accounted for about $60 \%$, followed by family farms $(35 \%)$ and farms managed by employees (5\%) (Figure 3 B).

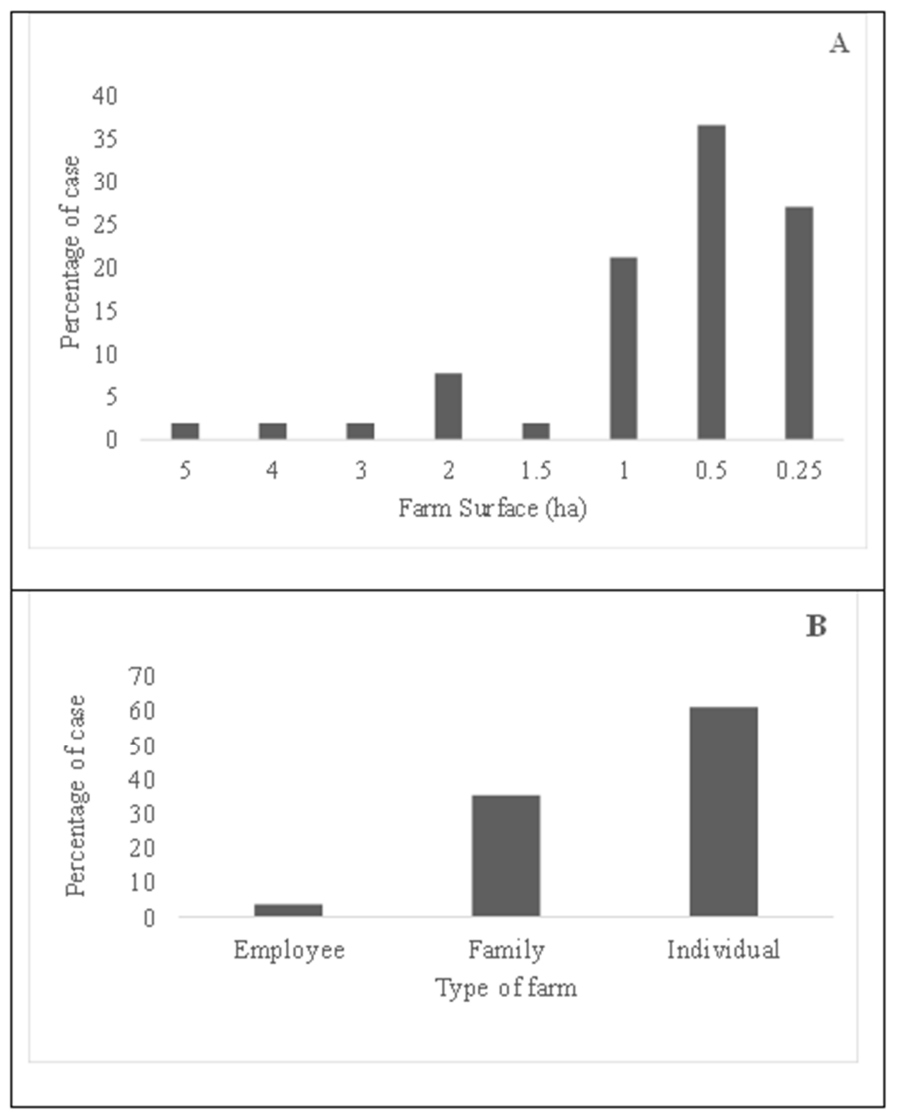

Figure 3. Farm size and type of farms in the Green belt of Ouagadougou, Burkina Faso.

\subsection{Cropping Practices}

There were about thirty (30) plant species (cereal and cash crops) grown in the Green belt. The most cultivated species (Table 1) are mainly cash crops which were widely consumed (okra, maize, salad, cowpeas / leaves and seeds, amaranth, peanut, sorrel, carrot, cabbage). Next were cereals (rice, white sorghum) for household consumption. The last batch of cultivated species (strawberry, corchorus, celery, cucumber, onions, spinach, local eggplant, millet, Green beans, watermelon, small weight or groundnut, potato, sesame, tomato.) included common plants. The yields of the cultivated crops were rated as good for $67.9 \%$ of respondents, against $17 \%$ who find them bad and $15.1 \%$ who think they are average. The production was intended either for consumption $(50 \%)$ or for sale according to the same proportions of respondents $(50 \%)$.

Table 1. Proportion of cultivated species encountered in the Green-belt of Ouagadougou, Burkina Faso.

\begin{tabular}{lll}
\hline Species & Water supply system & Percentage of responses \\
\hline Maize (Zea mays L.) & Rainfeed \\
Okra (Abelmoschus esculentus L) & Rainfeed \\
Cowpea (Vigna unguiculata (L.) ) Walp. & Rainfeed and Irrigation \\
Lettuce (Lactuca sativa L.) & Irrigation \\
Amaranth Amaranthus caudatus L. & Rainfeed and Irrigation \\
Peanut (Arachis hypogea L.) & Rainfeed \\
Sorrel (Hibiscus sabdariffa L.) & Rainfeed and Irrigation \\
Cabbage (Brassica oleracea var capitata) & Rainfeed and Irrigation \\
Carrot (Daucus carota L.) & Rainfeed and Irrigation \\
Rice (Oryza sativa L.) & Rainfeed \\
Sorghum (Sorghum bicolor (L.) Moench) & Rainfeed \\
Corchorus (Corchorus spp.) & Rainfeed \\
Strawberry (Fragaria ananassa L.) & Rainfeed and Irrigation \\
Celery (Apium graveolens var. dulce) & Rainfeed and Irrigation \\
Cucumber (Cucumis sativus L.) & Rainfeed and Irrigation \\
\hline
\end{tabular}




\begin{tabular}{lll}
\hline Species & Water supply system & Percentage of responses \\
\hline Mint (Mentha spp.) & Rainfeed and Irrigation & 2 \\
Onion (Allium cepa L.) & Rainfeed & 2 \\
African Eggplant (Solanum macrocarpon L.) & Rainfeed and Irrigation & 1 \\
Beetroot (Beta vulgaris var. rubra L.) & Rainfeed and Irrigation & 1 \\
Courgette (Cucurbita pepo L.) & Rainfeed and Irrigation & 1 \\
Green bean (Phaseolus vulgaris L.) & Rainfeed & 1 \\
Gynandropis (Cleome gynandra L.) & Rainfeed & 1 \\
Millet (Pennisetum glaucum (L.) R.Br.) & Rainfeed & 1 \\
Pea (Pisum sativum L.) & Rainfeed & 1 \\
Pepper (Capsicum annuum L) & Rainfeed & 1 \\
Potato (Solanum tuberosum L.) & Rainfeed & 1 \\
Sesame (Sesamum indicum L.) & Rainfeed & 1 \\
Spinach (Spinacia oleraceae L.) & Rainfeed and Irrigation & 1 \\
Tomato (Lycopersicom esculentum Mill.) & Rainfeed and Irrigation & 1 \\
Watermelon (Citrullus vulgaris Schrader) & Rainfeed & 1 \\
\hline
\end{tabular}

\subsection{Difficulties Encountered by Producers and Solutions}

The main problems faced by producers include lack of agricultural inputs, lack of irrigation water, low soil fertility, lack of work equipment (Table 2). Table 3 shows that about $13 \%$ of the producers did not have a solution to improve their cropping systems while $60 \%$ of them propose the support with credits, fountains and fertilizers are potential solutions.

Table 2. Difficulties encountered by the urban farmers in the Green-belt of Ouagadougou, Burkina Faso.

\begin{tabular}{ll}
\hline Difficulties encountered & Percentage of responses \\
\hline Lack of agricultural inputs & 28 \\
Lack of water & 20 \\
Lack of finances & 5 \\
Lack of equipment & 5 \\
Weeds pressure & 5 \\
Low soil fertility & 5 \\
Low rainfall & 4 \\
Lack of labor & 4 \\
Poor sales & 3 \\
Destructive organisms & 3 \\
Loitering of animals & 2 \\
Lack of storages & 2 \\
Lack of irrigation canal & 1 \\
Well not equipped & 1 \\
High cost of seed & 1 \\
High cost of fuel & 1 \\
Unsalubrious conditions & 1 \\
Lack of space & 1 \\
Low yields & 1 \\
None & 4 \\
\hline
\end{tabular}

Table 3. Solutions proposed by urban farmers to overcome difficulties in the Green-belt of Ouagadougou, Burkina Faso.

\begin{tabular}{ll}
\hline Solutions to the difficulties & Percentage of responses \\
\hline Increase water storage capacity & 1.59 \\
Develop the market & 1.59 \\
Donate wells & 1.59 \\
Develop Labor & 1.59 \\
Make more wells & 1.59 \\
Reorganize the canal store water & 1.59 \\
Provide support & 1.59 \\
Increase the surfaces & 3.17 \\
Subsidize seeds & 4.76 \\
Donate equipment & 7.94 \\
None & 12.7 \\
\hline
\end{tabular}

\begin{tabular}{ll}
\hline Solutions to the difficulties & Percentage of responses \\
\hline Donate credits & 19.1 \\
Construct fountains & 20.6 \\
Subsidize fertilizers & 20.6 \\
\hline
\end{tabular}

The PCA analysis shows that about $50 \%$ of the variability in cropping practice was explained by the first two canonical axes (Figure 4). The cropping of cereal and the cropping of vegetable were correlated with the first axis and determined by the age of the farmer, age of the farm, market orientation and gender. The combined cropping of vegetable and cereal were correlated with the second axis and determined by fertilization, land tenure, distance to house and farm size. The parameters education and type of farm did not influence a lot the cropping practices. The farmers owned the land were those who fertilize their fields. The oldest farms were held by men and were oriented to market.

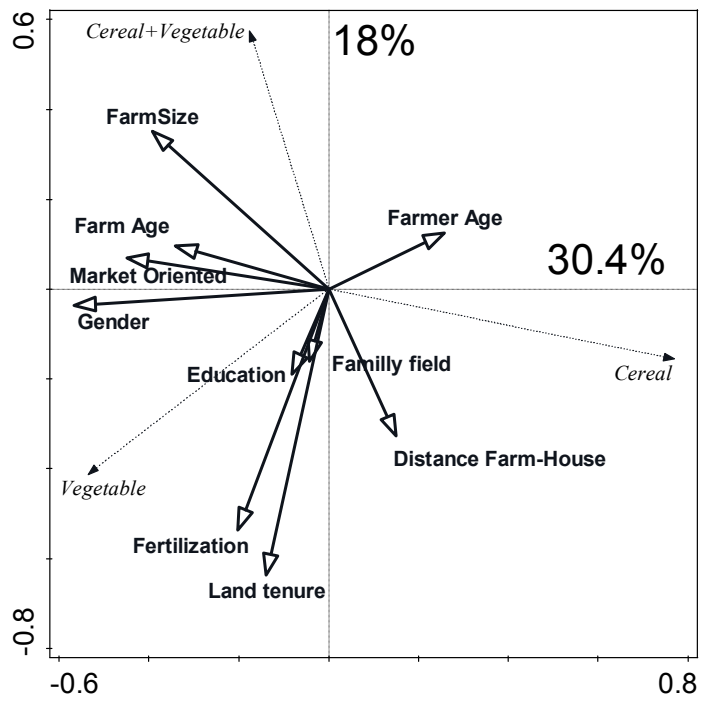

Figure 4. Variability of cropping practices (vectors in dotted lines) as explained by the socio-economic status (vectors in continuous lines) of farmers from the Green belt of Ouagadougou, Burkina Faso. Numbers are the percentage of the variability explained by the first two axes of the principal component analysis. Size and orientation of the vectors represent correlation among them and with the axes. The informations about education, type of farming, fertilization, market orientation and land tenure were encoded as dummy variables using 1 for the presence and 0 for the absence. The information about gender was encoded 1 for man and 0 for woman. 


\section{Discussion}

The age of the oldest farms estimated by the informants to 70 years old and the most recent to 1 year old suggest that the occupation of the Green belt is continuous even though its delimitation by the Water and Forests Department in 1976. The dominance of individual farmers indicates that land acquisition is not organized. Some operators occupy the sites because vacant spaces exist while others occupy empty spaces because they live in front of them. This situation is justified partly by the lack of visible boundaries limiting the Green belt for instance with identification panels [12]. The exploitation of the Green belt by people of all age suggest that there is no age restriction for land needs.

The strong presence of women is explained by the fact that they are the main producers of market gardening. In cities, women living in poor families, supported by young children, usually do most of the agricultural work while men work offfarm [25]. In general, it is the illiterate who occupy the land because it is difficult for them to work in the public or private sectors, where literacy is a key condition for getting a job.

According to the territory database of 1992, the area cultivated in the Green belt was 957.2 hectares. This area increased to 1602 hectares in 2012 (data not shown). A sharp increase in harvested areas is also observed and indicates that agricultural occupations are intensifying, suggesting an increased need for arable land in the city of Ouagadougou.

The mode of land acquisition thus remains informal because it is either a transaction as is done in the tradition or by voluntary occupation, the administration being kept apart in the process of acquisition of these lands. In situations like this, some people profit and make land speculation for the sole purpose of getting rich.

Most of the crops grown are all described in the Burkina Faso Agricultural Equipment Catalog by the Ministry of Agriculture and Food Security [24]. In general, they are well known plants and whose marketing is easy and fast. Producers find that yields are good because of the use of waste as fertilizer. However, these yields are dependent on rainfall. Besides, problems including health risks associated with the use of wastewater for watering plants [26] and the risk of soil pollution from urban waste [27] should be considered.

No informants mentioned problems with land occupation, which shows the lack of rules and governance. Nowadays, the Green belt whose functions and limits are in the layout of the city of Ouagadougou is used for other purposes contrary to the expectations at the time of its creation namely the practice of agroforestry. This indicates a lack of rigor on the part of the forest administration and communal officials in the management of urban spaces. At the beginning, agroforestry was practiced, but as the years passed, the trees planted were destroyed and the spaces put under cropping. Riparian populations were not really involved in the planting and maintenance of trees because labor was recruited and paid in cash. The consequence is that after the plantations, the lack of maintenance of the trees arose as a problem especially since the funding ended in 1986. The lack of a permanent management system of the Green belt led to the deforestation. The period 1975 to 1990 also corresponds to the end of the National Program to Combat Desertification (PNLCD) under German funding.

Two options arise in relation to the practice of agriculture in the Green belt. The first is to move producers to other areas such as the future agro-sylvo-pastoral zone of Koubri located $15 \mathrm{~km}$ from the city of Ouagadougou, defined by the "Master Plan of Development of "Grand Ouaga" in order to rehabilitate the Green belt. This option assumes that current operators of the Green belt will be forced to relocate their homes to move closer to new sites. The second option is to recreate the Green belt in a space where production and conservation are respected. We could then intensify agriculture to supply the city with local agricultural products, while preserving woody species. Accompanying measures through the provision of credit to producers for the acquisition of equipment and inputs and their training in the practice of organic farming and agroforestry are necessary. However, these measures can only be taken if the vocation of space is determined within the framework of a management plan that depends on the status of the entity.

To the extent that the existing and proposed Green belt is already materialized in the land occupation of the Ouagadougou Commune and its surroundings [28] and placing us in the context of decentralization, the option to give the Green Belt a specific function that guarantees sustainable development should be an application of the national legal instruments under which the Law $\mathrm{N}^{\circ} 055$ 2004/AN of 21 December 2004 on the General Code of Territorial Communities in Burkina Faso amended by the Law $\mathrm{n}^{\circ} 065-2009 / \mathrm{AN}$ of $09 / 12 / 2009$ [29] which in its articles 11 to 22 deals with the spaces of the Commune notably the space of production intended mainly for the agriculture, the animal husbandry, forestry, fish farming and more generally all activities related to rural life and the conservation area consisting of a natural resources protection zone. The law also devotes the competences of municipalities and regions in the field of space management. Thus, Burkina Faso has clearly shown its willingness to empower local and regional authorities in managing situations such as the Green belt. In 2005, the Ministry of the Environment adopted the Plan of Institutional and Legal Reforms for Decentralization in the Forestry Sector [30], together with a methodological guide for the creation and management of conservation by local authorities. In addition, Law N ${ }^{\circ}$ 003-2011/AN of 05 April 2011 on the Forestry Code in Burkina Faso in Articles 11 to 22 is a reference for defining the functions of a space such as the Green Belt and its status taking into account the area, the exact boundaries of the forest, its main or exclusive uses and the modalities of its management [31].

The analysis of these legal texts allows the following propositions: i) classify spaces in the name of the State or in the name of the Commune $(75 \%$ of the districts of 
Ouagadougou are concerned by the Green belt), ii) make a typology of the actors on the ground having a status which will depend on the function of the space and to organize the actors present on the site for agroforestry or horticultural exploitation (organization with declaration of existence), iii) develop a management plan depending on the function chosen for the area (agricultural and forestry production, horticultural production), iv) consider management options, either state-managed or a concession to natural or legal persons (structures with a status that will depend on the function of the space) or to entrust the management of the entity to private operators, v) set up an exchange framework or build on the already existing Ouagadougou Commune's consultation framework, vi) elaborate precise specifications for the exploitation, vii) grant the management of space to the structures identified and organized, by administrative acts of concession. These propositions when applied and strictly monitored will be useful to avoid conflicts as currently experienced with the Kua forest in Bobo-Dioulasso [32, 33].

\section{Conclusion}

The Greenbelt of Ouagadougou was farmed for many years. Despite its delimitation followed by the planting of trees. Farmers were young men, and adult women and men as well. Individual farms were dominant and land acquisition remained informal. The most cultivated species were mainly cereal and vegetable crops for sale and consumption. The cropping practices of the farmers are determined by the land tenure, age of farmers, gender, age and size of farms and market orientation. The main problems faced by producers included lack of agricultural inputs, lack of irrigation water and lack of work equipment. It appeared that producers do not encounter any problem to occupy the lands in the Green belt. This paper highlighted the complexity of applying agroforestry in peri-urban areas and the need for collaboration between the forest management services and the urban stakeholders including municipal authorities and those in charge of land planning. The option to take into account the protection of the city against pollution, the protection of the ecosystem while providing food for the city, would be the concession of the management of the entity to people endorsing administrative and legal acts followed by a multi-sectoral and multidisciplinary exchange framework. From technical point of view, the Greenbelt can be rehabilitated while moving producers to the peri-urban areas where crops production is already practiced. Another option would be to recreate a green belt by moving it to area where crop production combined with conservation of trees can be introduced and accepted by the population trough awareness raising.

\section{Acknowledgements}

The authors thank Stéphane Ilboudo who contributed to the collection of data, Haoua Ouédraogo who contributed to the investigations on farms, Adama Kalmogo for his contribution to the litterature review and Göran Björkdahl who contributed to the review of the manuscript.

\section{References}

[1] FAO (2011). Produire plus avec moins. Guide à l'intention des décideurs sur l'intensification durable de l'agriculture paysanne. $116 \mathrm{p}$.

[2] FAO (2018). L'avenir de l'alimentation et de l'agriculture Parcours alternatifs d'ici à 2050. Rome. 64 p.

[3] FAO (2017). Regional Overview of Food Security and Nutrition in Africa 2016. The challenges of building resilience to shocks and stresses. Accra. $40 \mathrm{p}$.

[4] Edame, G. E., Ekpenyong, A. B., Fonta, W. M., Duru, E. J. C. (2011). Climate Change, Food Security and Agricultural Productivity in Africa: Issues and policy directions. International Journal of Humanities and Social Science 21: 205-223.

[5] Temple L., Moustier P. (2003). L'agriculture péri-urbaine en Afrique tropicale: caractéristiques, fonctions, contraintes et opportunités à partir d'études de cas. SEREIN Occasional Paper No 15: 39-58.

[6] Karg, H. (2018). Urban Food Supply. In Karg, H. Drechsel, P. (Eds.). 2018. Atlas of West African urban food systems: examples from Ghana and Burkina Faso. Colombo, Sri Lanka: International Water Management Institute (IWMI). CGIAR Research Program on Water, Land and Ecosystems (WLE) pp 36-37.

[7] Nahmias, P., Le Caro, Y. (2012). Les défis et les perspectives de l'agriculture urbaine Pour une définition de l'agriculture urbaine: réciprocité fonctionnelle et diversité des formes spatiales. Environnement Urbain / Urban Environment Volume 6, 17 p.

[8] FAO (2011). The place of urban and peri-UA (UPA) in national food security program. Integrated food security support service (TCSF) policy and program development support division technical cooperation department. Rome. 46 p.

[9] Magazine de l'agriculture urbaine. Vol 19. Promouvoir les innovation dans l'agriculture urbaine. $48 \mathrm{p}$.

[10] Rouchiche, S. (2001). La foresterie urbaine et périurbaine en Afrique une étude de cas sur le sahel (Dakar, Niamey, Nouakchott et Ouagadougou). www.fao.org/3/X3994F/X3994F01.htm2001 (accessed in April 2019).

[11] Awal, H. M. (2015). La métropole-village (s) de Ouagadougou: explorer les potentiels d'un territoire, supports de processus de projet architectural. Architecture, aménagement de l'espace. Université Grenoble Alpes.

[12] Kalmogo, A. (2017). La ceinture verte de la ville de Ouagadougou: état des lieux et perspectives de réhabilitation. Mémoire de fin de cycle Inspecteurs des Eaux et Forêt. Ecole Nationale des Eaux et Forêts de Dindéresso, Bobo-Dioulasso. $91 \mathrm{p}$.

[13] MHU (Ministère de l'Habitat et de l'Urbanisme). (2010). Schéma Directeur d'Aménagement du Grand Ouaga Horizon 2025. Volume 1. Le portrait du grand Ouaga. 216 p. 
[14] Aboubacar, A. (2018). Dégradation de la ceinture verte de Niamey. Niger Inter Magazine $\mathrm{N}^{\circ} 010$ Mars 2018. Accessible au site: https:/www.nigerinter.com/2018/03/degradation-dela-ceinture-verte-de-niamey/ (accessed in April 2019).

[15] Sanga B., Ouehoura F., Tietiembou T. (2012). Projet d'aménagement de la "ceinture verte": des poumons verts à Ouagadougou pour une vie meilleure. Accessible au site: http://lefaso.net/spip.php?article46177(accessed in April 2019).

[16] MEEVCC (Ministère de l'Environnement, de l'Economie Verte et $\mathrm{du}$ Changement Climatique). (2017). Note d'information sur la ceinture verte de Ouagadougou. Comité de mise en œuvre de la réhabilitation. 5 p.

[17] MEEVCC (Ministère de l'Environnement, de l'Economie Verte et du Changement Climatique). (2017). Arrêté N ${ }^{\circ} 2017-$ 261/MEEVCC/CC/CAB portant création, attributions, composition et fonctionnement du comité de mise en œuvre de la réhabilitation de la ceinture verte de la ville de Ouagadougou, du 14 juillet 2017.

[18] CES (Conseil Economique et Social). (2017). Rapport de la deuxième session ordinaire de l'année 2017. Recommandation relative à la réhabilitation et à la protection de la ceinture verte de Ouagadougou, 29 novembre 2017.

[19] SP-CONEDD (2010). Troisième rapport sur l'état de l'environnement au Burkina Faso. P66, 263p.

[20] Zida Y. (2009). Monographie de la région du Centre. Ministère de l'Economie et des Finances. 154p.

[21] Nacoulma-Ouédraogo, O. G. (1996). Plantes médicinales et pratiques médicales traditionnelles au Burkina Faso: cas du plateau central. Thèse de doctorat d'Etat, Faculté des Sciences et Techniques, Université de Ouagadougou, Burkina Faso, tome $1,320 \mathrm{p}$, tome 2, p285.

[22] Thiombiano A. Schmidt M.; Dressler S.; Ouédraogo A.; Hahn K., Zizka, G. (2012). Catalogue des plantes vasculaires du Burkina Faso. Boissiera volume 65. 391 p.

[23] Brink, M. \& Belay, G. (Editeurs), (2006). Ressources végétales de l'Afrique tropicale 1. Céréales et légumes secs. [Traduction de: Plant Resources of Tropical Africa 1. Cereals and pulses. 2006]. Fondation PROTA, Wageningen, Pays-Bas
/ Backhuys Publishers, Leiden, Pays-Bas / CTA, Wageningen, Pays-Bas. 328 pp.

[24] MASA (Ministère de l'Agriculture et de la Sécurité Alimentaire) - Ministère de la Recherche Scientifique et de l'Innovation - Ministère de l'Environnement et du Développement Durable. (2014). Catalogue national des espèces et variétés agricoles du Burkina Faso. 81 p.

[25] Prain, G. (2008). Promouvoir l'innovation technique, organisationnelle et institutionnelle dans l'agriculture urbaine. Magazine de l'Agriculture Urbaine 19: 3-11.

[26] Ouédraogo, D. B., Gnankambary, Z., Nacro H. B., Sedogo P. M. (2018). Caractérisation et utilisation des eaux usées en horticulture dans la ville de Ouagadougou au Burkina Faso. International Journal of Biology and Chemical Science 12: 2564-2577.

[27] Kiba, D. I., Zongo, N. A., Lompo, F., Jansa, J., Compaore, E., Sedogo, P. M., Frossard, E. (2012). The diversity of fertilization practices affects soil and crop quality in urban vegetable sites of Burkina Faso. European Journal of Agronomy 38: 12-21.

[28] Burkina Faso. (2017). Schéma national d'aménagement et de développement durable du territoire (SNADDT) 2040. 165 P.

[29] Burkina Faso. (2010). JO nº ${ }^{\circ}$. Loi 065-2009/AN du 09/12/2009 modifiant la Loi ${ }^{\circ} 055-2004 / A N$ du 21 décembre 2004 portant Code général des collectivités territoriales au Burkina Faso.

[30] MECV et FAO (2006). Plan d'action pour la mise en œuvre des Réformes Institutionnelles et Juridiques pour la Décentralisation dans le Secteur Forestier au Burkina Faso (Rapport final), $119 \mathrm{p}$.

[31] Burkina Faso. (2011). Loi no 03-2011/AN du 28 avril 2011 portant Code forestier au Burkina Faso.

[32] Diallo, A. (2019). Au Burkina, polémique sur un projet d'hôpital financé par la Chine dans la forêt classée de Kua. In jeune Afrique Accessible sur: https://www.jeuneafrique.com/pays/burkina-faso/. (accessed in June 2019).

[33] Sidwaya. (2019). N $\mathrm{N}^{\circ} 8904$ du Vendredi 24 au Dimanche 26 Mai $2019 \mathrm{~N}^{\circ} 8904$ Paru le Vendredi 24 Mai 2019. 